\title{
Detection of SARS-CoV-2 in conjunctival secretions from patients without ocular symptoms
}

\author{
Xin $\mathrm{Li}^{1}$ · Jasper Fuk-Woo Chan ${ }^{2,3,4,5} \cdot$ Kenneth Kai-Wang $\mathrm{Li}^{6}$ • Eugene Yuk-Keung Tso ${ }^{7}$ Cyril Chik-Yan Yip ${ }^{1}$. \\ Siddharth Sridhar ${ }^{2,3,4} \cdot$ Tom Wai-Hin Chung $^{1} \cdot$ Kelvin Hei-Yeung Chiu ${ }^{1} \cdot$ Derek Ling-Lung Hung ${ }^{1}$. \\ Alan Ka-Lun $\mathrm{Wu}^{8}$. Sandy Ka-Yee Chau ${ }^{9} \cdot$ Raymond Liu $^{10} \cdot$ Kwok-Cheung Lung $^{11}$. Anthony Raymond Tam ${ }^{13}$. \\ Vincent Chi-Chung Cheng ${ }^{1}$. Kelvin Kai-Wang To ${ }^{2,3,4} \cdot$ Kwok-Hung Chan $^{2,3,4} \cdot$ Ivan Fan-Ngai Hung ${ }^{4,12,13}$. \\ Kwok-Yung Yuen $2,3,4,5$
}

Received: 7 July 2020 / Accepted: 7 September 2020 / Published online: 17 September 2020

(c) Springer-Verlag GmbH Germany, part of Springer Nature 2020

\begin{abstract}
Purpose To evaluate the presence of severe acute respiratory syndrome coronavirus 2 (SARS-CoV-2) in conjunctival secretions from patients without ocular symptoms.

Methods Conjunctival swabs were prospectively collected from laboratory-confirmed Coronavirus disease 2019 (COVID19) patients without ocular symptoms for reverse transcription-polymerase chain reaction (RT-PCR) and viral culture.

Results A total of 158 conjunctival swabs were obtained from 49 laboratory-confirmed COVID-19 patients. The median duration of illness when the first conjunctival swab was obtained was 10 days (range 2-27 days). Four conjunctival swabs from four different patients $(4 / 49,8.2 \%)$ were positive for SARS-CoV-2 RNA by RT-PCR. The Ct values ranged from 32.7 to 37.7 (mean 35.4). Viral cultures were negative for all four RT-PCR-positive conjunctival swabs.

Conclusion Conjunctival secretions of a minority of COVID-19 patients without ocular symptoms may contain relatively low levels of SARS-CoV-2 RNA, but their infectiousness remains undetermined. Appropriate infection control measures should be implemented during ophthalmological assessment of COVID-19 patients to prevent potential nosocomial transmission of SARS-CoV-2.
\end{abstract}

Keywords SARS-CoV-2 $\cdot$ Conjunctiva $\cdot$ Asymptomatic $\cdot$ Shedding $\cdot$ RT-PCR

\section{Introduction}

In December 2019, a cluster of respiratory illness of unknown cause was reported in Wuhan, Hubei Province, China [1]. The infectious agent, now named severe acute respiratory syndrome coronavirus 2 (SARS-CoV-2), was identified to be a member of the genus Betacoronavirus and subgenus Sarbecovirus [2]. It is phylogenetically closely related to SARS-related coronaviruses in bats [3]. Within 6 months, SARS-CoV-2 has evolved into a global pandemic

Xin Li, Jasper Fuk-Woo Chan and Kenneth Kai-Wang Li contributed equally.

Ivan Fan-Ngai Hung

ivanhung@hku.hk

Extended author information available on the last page of the article with more than 8 million laboratory-confirmed cases and over 0.4 million deaths [4].

The clinical manifestations of SARS-CoV-2 infection, or Coronavirus disease 2019 (COVID-19), range from asymptomatic or subclinical infections, to acute viral pneumonitis with respiratory failure and/or multi-organ dysfunction [5-7]. Case reports and small retrospective cohorts of conjunctivitis as a presenting feature of SARS-CoV-2 infection emerged since the early phase of the pandemic. But the prevalence of ocular symptoms was reported to be $<1 \%$ in larger case series [5].

SARS-CoV-2 has been detected in different bodily fluids, including respiratory secretions, blood, and feces $[8,9]$. SARS-CoV-2 RNA has been detected by reverse transcription-polymerase chain reaction (RT-PCR) in the conjunctival secretions in a number of patients, and by viral culture in one patient in Rome [10-21]. Conjunctival secretions may, therefore, be a potential source of transmission of SARS-CoV-2. 
However, the rate of asymptomatic shedding of SARS$\mathrm{CoV}-2$ in conjunctival secretions remains unknown.

\section{Objective}

In the present study, we investigated the presence of SARSCoV-2 in conjunctival swabs of laboratory-confirmed COVID-19 patients without ocular symptoms.

\section{Study design}

\section{Subjects and clinical specimens}

This multi-center prospective study was conducted at four public hospitals in Hong Kong. Adult ( $\geq 18$ years old) patients confirmed with COVID-19 by RT-PCR of nasopharyngeal specimens and admitted to four regional hospitals (Queen Mary Hospital, United Christian Hospital, Pamela Youde Nethersole Hospital, and Ruttonjee Hospital) from February to March 2020 in Hong Kong Special Administrative Region, China were recruited. This study was approved by the Institutional Review Board of the University of Hong Kong/Hospital Authority. Written consents were obtained from all recruited patients. Forty one of the 49 recruited patients were enrolled in an open-label, randomized, phase- 2 trial on triple combination of interferon $\beta-1 b$, lopinavir-ritonavir, and ribavirin for treatment of patients hospitalized with COVID-19 [22], and the remaining 8 patients were enrolled in a case series on returnees from a cruise ship [23]. Conjunctival swabs were prospectively collected from recruited patients during hospitalization using transport swabs (Copan Italia, Brescia, Italy) following standardized protocol for conjunctival sampling. Informed consent was obtained from each patient before each procedure. Adequate conjunctival tissue was obtained by sweeping the lower fornix of each eye with the swab for 3 times. The swabs were immediately placed into $2 \mathrm{~mL}$ viral transport medium as described previously [24]. The specimens were sent to the laboratory of the Department of Microbiology in Queen Mary Hospital for testing.

\section{Nucleic acid extraction}

TNA extraction was performed using NucliSENS easyMAG extraction system (BioMerieux, Marcy-l'Étoile, France) according to manufacturer's instructions and as previously described $[9,25,26]$. Briefly, $250 \mu \mathrm{L}$ of each conjunctival swab was subjected to extraction with an elution volume of $55 \mu \mathrm{L}$. The extracts were stored at $-80{ }^{\circ} \mathrm{C}$ until use.
SARS-CoV-2 RNA detection by real-time reverse transcription-polymerase chain reaction (RT-PCR) assay

SARS-CoV-2 RNA in the conjunctival swabs was detected by RdRp/Hel RT-PCR assay using QuantiNova Probe RTPCR Kit (QIAGEN, Hilden, Germany) on LightCycler 480 II Real-Time PCR System (Roche, Basel, Switzerland) as described previously [8]. Briefly, each $20 \mu \mathrm{L}$ reaction mixture contained $10 \mu \mathrm{L}$ of $2 \times$ QuantiNova Probe RT-PCR Master Mix, $0.2 \mu \mathrm{L}$ of QN Probe RT-Mix, $1.6 \mu \mathrm{L}$ of each $10 \mu \mathrm{M}$ forward and reverse primers, $0.4 \mu \mathrm{L}$ of $10 \mu \mathrm{M}$ probe, 1.2 $\mu \mathrm{L}$ of nuclease-free water and $5 \mu \mathrm{L}$ of TNA as the template. The thermal cycling condition was $45^{\circ} \mathrm{C}$ for $10 \mathrm{~min}, 95^{\circ} \mathrm{C}$ for $5 \mathrm{~min}$, followed by 45 cycles of $95^{\circ} \mathrm{C}$ for $5 \mathrm{~s}$ and $55^{\circ} \mathrm{C}$ for $30 \mathrm{~s}$.

\section{Viral culture of conjunctival swabs}

The conjunctival swabs were inoculated on VeroE6 cells. The inoculated cells were monitored daily for cytopathic effect by light microscopy for up to 7 days, and cells were tested for nucleoprotein (NP) expression of SARS-CoV-2 by immunofluorescence test [27].

\section{Literature search and study selection}

We performed literature search on PubMed using the keywords "SARS-CoV-2", "COVID-19", or "2019-nCoV", and "conjunctiva" or "conjunctivitis". All peer-reviewed articles in English between 1 December 2019 and 16 June 2020 were screened. Original articles, editorials, commentaries, and letters which identified patients with positive testing for SARS-CoV-2 from conjunctival/ocular swabs or secretions, either by RT-PCR or viral culture, with or without conjunctival symptoms, were included. All articles were imported to Endnote X9.3.2 (Thompson and Reuters, Philadelphia, PA, USA), and duplicates were removed.

\section{Results}

\section{Patient demographics and clinical characteristics}

A total of 49 laboratory-confirmed COVID-19 patients were included in the study. There were 17 males and 32 females. Fever was present in 21 patients $(42.9 \%)$ at presentation. Respiratory symptoms, including cough, dyspnea, sore throat and/or rhinorrhea were present in 34 patients (69.4\%). Only one patient required intubation and admission 
to intensive care units (ICU). Ocular symptoms were absent in all 49 patients throughout the course of illness. The clinical details are summarized in Table 1 .

\section{SARS-CoV-2 shedding in conjunctival secretions}

A total of 158 conjunctival swabs were obtained from these 49 patients (mean 3.2 swabs per patient). The median duration of illness when the first conjunctival swab was obtained was 10 days (range 2-27). The duration of illness was calculated from the day of symptom onset or day of first positive nasopharyngeal specimen in asymptomatic patients. Four conjunctival swabs from four different patients (4/49, $8.2 \%$ ) were positive for SARS-CoV-2 RNA by RT-PCR, including one male and three females with a mean age of 47.3 years (range 28-63). The $\mathrm{Ct}$ values ranged from 32.7 to 37.7 (mean 35.4). The SARS-CoV-2-positive conjunctival swabs were collected between three to twelve days after symptom onset (mean 6.3 days). None of these four patients had severe disease requiring mechanical intubation or admission to ICU. Concomitant nasopharyngeal specimens were RT-PCR-positive for SARS-CoV-2 in two patients. Viral cultures were negative for all four RT-PCR-positive conjunctival swabs. The clinical details of these four patients are listed in Table 2.

\section{Evidence of conjunctival SARS-CoV-2 shedding in the literature}

Our literature search identified 70 articles on PubMed, including 20 case reports/series which were included for analysis. A total of 17 patients with conjunctival/ocular swabs or secretions positive for SARS-CoV-2 RNA by RTPCR are reported (Table 3 ). The age ranged from 34 months to 70 years. When their gender was reported, males and females were approximately equally affected (6 males vs. 4 females). Among the six studies that reported the $\mathrm{Ct}$ values of the SARS-CoV-2-positive conjunctival/ocular specimens, the values ranged from 21.7 to 37 .

As early as 22 January 2020, a Chinese doctor in the national expert panel reported that he likely contracted SARS-CoV-2 from conjunctival route during inspection in Wuhan [28]. N95 respirator and protective gowns were worn during the trip but the eyes were left unprotected. In retrospect, he reported unilateral conjunctivitis $2-3 \mathrm{~h}$ before the onset of fever and respiratory symptoms. However, no virological confirmation by RT-PCR or viral culture of ocular specimens was described. Xia et al. first described SARSCoV-2 RT-PCR-positive conjunctival swabs in a patient with conjunctivitis [10]. The first positive specimen was collected 3 days after disease onset. The patient had no fever or respiratory symptoms but SARS-CoV-2 RT-PCR of the patient's sputum was positive both on admission and on days of conjunctival specimen collection. All 58 conjunctival swabs from another 29 patients without conjunctival symptoms in this report were negative, including nine patients with severe SARS-CoV-2 infection. Except for the case reported by Cheema et al. [12], most case reports of conjunctivitis as a sole presenting sign of SARS-CoV-2 infection either did not collect or failed to identify SARS-CoV-2 in ocular specimens by RT-PCR.

In most of the reported cases, conjunctivitis was described as a self-limiting condition. Topical ribavirin eye drops were added to systemic antivirals for treatment in one patient with bilateral acute conjunctivitis manifested on day 13 of illness, with viral clearance from conjunctival swab on day 6 of topical ribavirin [13]. In a patient from Italy, prolonged shedding of SARS-CoV-2 was detected in ocular swabs until day 27
Table 1 Demographic and clinical characteristics of included patients $(n=49)$

\begin{tabular}{ll}
\hline Parameter & Value \\
\hline Age & 57.1 (range 21-96) years \\
Sex & \\
Male & $17(34.7 \%)$ \\
Female & $32(65.3 \%)$ \\
Fever at presentation & $21(42.9 \%)$ \\
Respiratory symptoms at presentation ${ }^{\mathrm{a}}$ & $34(69.4 \%)$ \\
Baseline nasopharyngeal swab viral $\operatorname{load}\left(\log _{10}\right.$ copies $\left./ \mathrm{mL}\right)$ & $5.2(3.9-6.7)$ \\
Baseline lymphocyte count $\left(\right.$ Ref. interval $\left.0.6-4.3 \times 10^{9} \mathrm{cells} / \mathrm{L}\right)$ & $1.4(1-1.7)$ \\
Baseline lactate dehydrogenase level $($ Ref. interval $<248 \mathrm{U} / \mathrm{L})$ & $220.5(167.8-280)$ \\
Duration of illness at first conjunctival specimen collection $(\mathrm{median})$ & $10($ range $2-27)$ days \\
Antiviral treatment & \\
Interferon $\beta-1 b$, lopinavir/ritonavir, and ribavirin & $12(24.5 \%)$ \\
Lopinavir/ritonavir and ribavirin & $16(32.7 \%)$ \\
Lopinavir/ritonavir alone & $15(30.6 \%)$ \\
Nil & $6(12.2 \%)$ \\
\hline
\end{tabular}

${ }^{a}$ Respiratory symptoms include cough, dyspnoea, rhinorrhoea, and sore throat 
Table 2 Clinical details of patients with positive SARS-CoV-2 RT-PCR in conjunctival swabs

\begin{tabular}{|c|c|c|c|c|}
\hline & Patient 1 & Patient 2 & Patient 3 & Patient 4 \\
\hline Gender & $\mathrm{F}$ & M & $\mathrm{F}$ & $\mathrm{F}$ \\
\hline Age (years) & 63 & 57 & 28 & 41 \\
\hline Fever on presentation & No & Yes & Yes & No \\
\hline Respiratory symptoms ${ }^{\mathrm{a}}$ & Yes & Yes & No & No \\
\hline $\begin{array}{l}\text { Days of conjunctival specimen collection (bolded: day of } \\
\text { positive conjunctival specimen collection) }\end{array}$ & $11, \mathbf{1 2}, 13$ & $5, \mathbf{6}, 7,8,9,10$ & 3 & 2,4 \\
\hline $\mathrm{Ct}$ value & 36.1 & 34.9 & 37.7 & 32.7 \\
\hline Concomitant nasopharyngeal specimen ${ }^{\mathrm{b}}$ & Negative & N/A & Positive & Positive \\
\hline $\begin{array}{l}\text { Baseline nasopharyngeal swab viral } \operatorname{load}_{\text {( }} \log _{10} \text { copies/ } \\
\mathrm{mL} \text { ) }\end{array}$ & 5.82 & 8.29 & 6.66 & 5.11 \\
\hline $\begin{array}{l}\text { Baseline lymphocyte count (Ref. interval 0.6-4.3 × } 10^{9} \\
\text { cells/L) }\end{array}$ & 2.08 & 1.44 & 2.17 & 0.77 \\
\hline $\begin{array}{l}\text { Baseline lactate dehydrogenase level (Ref. interval }<248 \\
\text { U/L) }\end{array}$ & 167 & 191 & 143 & 148 \\
\hline Need for oxygen support & No & No & No & No \\
\hline Need for intensive care & No & No & No & No \\
\hline $\begin{array}{l}\text { Day of first negative nasopharyngeal specimen from } \\
\text { symptoms onset }\end{array}$ & 11 & 21 & 17 & 7 \\
\hline Antiviral treatment & Lopinavir/ritonavir & Lopinavir/ritonavir & Lopinavir/ritonavir & $\begin{array}{l}\text { Interferon } \beta-1 b \text {, } \\
\text { lopinavir/ritona- } \\
\text { vir, and ribavirin }\end{array}$ \\
\hline
\end{tabular}

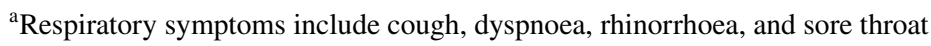

${ }^{\mathrm{b}}$ Collected within $24 \mathrm{~h}$ of conjunctival swab collection

of illness despite apparent resolution of conjunctivitis and undetectable viral load in nasal swabs [15], suggesting sustained viral replication in the conjunctiva. This patient also had the lowest $\mathrm{Ct}$ value from ocular swab (21.6) amongst all reported cases and was the only one with positive viral culture in VeroE6 cells. One of the patients in our study (patient 1) had positive conjunctival swabs on day 12 of illness, when her nasopharyngeal specimen had turned negative, which suggested that asymptomatic ocular shedding of SARS-CoV-2 may persist beyond respiratory tract shedding.

\section{Discussion}

In this study, we prospectively investigated the presence of SARS-CoV-2 shedding in conjunctival secretions of COVID-19 patients without ocular symptoms. There have been isolated case reports in the literature showing that SARS-CoV-2 RNA can be detected by RT-PCR from the conjunctival swabs of patients without ocular symptoms, suggesting that asymptomatic viral shedding from conjunctival secretions is possible $[16,18-20]$. The prevalence of ocular symptoms varied in different studies of SARS-CoV-2 infection. In a large case series comprising 1099 confirmed COVID-19 cases in China, only $0.8 \%$ presented with conjunctival congestion [5]. However, a later report showed that prodromal ocular symptoms were present in $11 \%$ of patients and new onset or aggravated ocular symptoms, such as dry eyes, eye soreness, and foreign body sensation, occurred in $27 \%$ of patients by retrospective questionnaires [29]. The incidence rate was similar in another report from Hubei, China, in which $\sim 30 \%$ of patients had ocular symptoms and $16.7 \%$ of them had SARS-CoV-2 RT-PCR-positive conjunctival swabs [14]. The predominant ocular symptoms among the patients in this latter study were conjunctival hyperaemia, chemosis, epiphora, and increased secretions. These findings suggested that the varying rates of ocular symptoms among different studies might be partly due to the different clinical criteria employed and background rate of nonspecific ocular symptoms in the general population.

In our study, we identified SARS-CoV-2 RNA shedding in the conjunctival secretions of 4 of $49(8.2 \%)$ patients without ocular symptoms. The apparently higher rate in this study than in previous reports might be due to repeated testing on several days for most recruited subjects (31 out of 49 [63.3\%] of them had at least 2 conjunctival swabs taken), which improved the detection of SARS-CoV-2 in specimens with low viral load or intermittent shedding. The mean $\mathrm{Ct}$ value of four patients with positive SARS-CoV-2 RT-PCR results in our study was 35.4. Three of them had more than 2 conjunctival swabs taken ( 2 for patient 4,3 for patient 1 , and 6 for patient 2), but only one of the conjunctival swabs 
Table 3 Characteristics of patients with positive ocular specimens for SARS-CoV-2 by molecular testing

\begin{tabular}{|c|c|c|c|c|c|c|c|c|}
\hline Reference & Sex/age & $\begin{array}{l}\text { Respiratory } \\
\text { symptoms }\end{array}$ & $\begin{array}{l}\text { Ocular symp- } \\
\text { tom }\end{array}$ & Specimen type & $\mathrm{Ct}$ value & Viral culture & $\begin{array}{l}\text { Concomitant } \\
\mathrm{NP} / \mathrm{OP} / \mathrm{P} \\
\text { specimen } \mathrm{Ct} \\
\text { value }\end{array}$ & $\begin{array}{l}\text { Antiviral treat- } \\
\text { ment }\end{array}$ \\
\hline Xia et al. [10] & $\mathrm{M} / 53$ & N/A & Conjunctivitis & $\begin{array}{l}\text { Conjunctival } \\
\text { swab }\end{array}$ & N/A & Negative & N/A & Nil \\
\hline $\begin{array}{l}\text { Zhang et al. } \\
\text { [11] }\end{array}$ & $F / 29$ & Nil & $\begin{array}{l}\text { Bilateral con- } \\
\text { junctivitis }\end{array}$ & $\begin{array}{l}\text { Conjunctival } \\
\text { swab }\end{array}$ & N/A & N/A & Positive & Nil \\
\hline $\begin{array}{l}\text { Cheema et al. } \\
\text { [12] }\end{array}$ & $F / 29$ & $\begin{array}{l}\text { Rhinorrhoea, } \\
\text { cough, nasal } \\
\text { congestion }\end{array}$ & $\begin{array}{l}\text { Unilateral } \\
\text { keratocon- } \\
\text { junctivitis }\end{array}$ & $\begin{array}{l}\text { Conjunctival } \\
\text { swab }\end{array}$ & 37 & N/A & $23-25$ & Nil \\
\hline Chen et al. [13] & $\mathrm{M} / 30$ & Sore throat & $\begin{array}{l}\text { Bilateral acute } \\
\text { follicular con- } \\
\text { junctivitis }\end{array}$ & $\begin{array}{l}\text { Conjunctival } \\
\text { swab }\end{array}$ & 31 & N/A & 23.5 & $\begin{array}{l}\text { Ribavirin eye } \\
\text { drop + umifeno- } \\
\text { vir, lopinavir/ } \\
\text { ritonavir }\end{array}$ \\
\hline \multirow[t]{2}{*}{$\begin{array}{l}\text { Bilateral con- } \\
\text { junctivitis }\end{array}$} & 21.7 & Conjunctivitis & & $\begin{array}{l}\text { Conjunctival } \\
\text { swab }\end{array}$ & N/A & N/A & Positive & Nil \\
\hline & $\mathrm{F} / 60 \mathrm{~s}$ & Cough & Chemosis & $\begin{array}{l}\text { Conjunctival } \\
\text { swab }\end{array}$ & N/A & N/A & Positive & Nil \\
\hline $\begin{array}{l}\text { Colavita et al. } \\
\text { [15] }\end{array}$ & $\mathrm{F} / 65$ & $\begin{array}{l}\text { Cough, sore } \\
\text { throat, coryza }\end{array}$ & & & & Positive & & Nil \\
\hline Hu et al. [16] & $\mathrm{M} / 70$ & Cough, sputum & Nil & Eye swab & $\sim 36$ & N/A & Not detected & $\begin{array}{l}\text { Lopinavir/rito- } \\
\text { navir, nebulised } \\
\text { interferon, TCM }\end{array}$ \\
\hline $\begin{array}{l}\text { Khavandi et al. } \\
\text { [17] }\end{array}$ & $\mathrm{M} / 65$ & $\begin{array}{r}\text { Dry cough, } \\
\text { dyspnoea }\end{array}$ & $\begin{array}{l}\text { Follicular con- } \\
\text { junctivitis }\end{array}$ & $\begin{array}{l}\text { Conjunctival } \\
\text { secretion }\end{array}$ & N/A & N/A & Positive & $\begin{array}{l}\text { Hydroxychloro- } \\
\text { quine }\end{array}$ \\
\hline \multirow[t]{3}{*}{$\begin{array}{l}\text { Karimi et al. } \\
{[18]}\end{array}$} & N/A & N/A & $\begin{array}{l}\text { Bilateral con- } \\
\text { junctivitis }\end{array}$ & Tears & N/A & N/A & Positive & Nil \\
\hline & N/A & N/A & Nil & Tears & N/A & N/A & Positive & Nil \\
\hline & N/A & N/A & Nil & Tears & N/A & N/A & Positive & Nil \\
\hline \multirow[t]{3}{*}{$\begin{array}{l}\text { Valente et al. } \\
\text { [19] }\end{array}$} & 180 months & Present & $\begin{array}{l}\text { Mild conjunc- } \\
\text { tivitis }\end{array}$ & $\begin{array}{l}\text { Conjunctival } \\
\text { swab }\end{array}$ & N/A & N/A & Positive & Nil \\
\hline & 52 months & Nil & Nil & $\begin{array}{l}\text { Conjunctival } \\
\text { swab }\end{array}$ & N/A & N/A & Positive & Nil \\
\hline & 34 months & Present & Nil & $\begin{array}{l}\text { Conjunctival } \\
\text { swab }\end{array}$ & N/A & N/A & Positive & Nil \\
\hline $\begin{array}{l}\text { Kumar et al. } \\
\text { [20] }\end{array}$ & $\mathrm{M} / 24$ & Nil & Nil & $\begin{array}{l}\text { Conjunctival } \\
\text { swab }\end{array}$ & 33 & N/A & Positive & Nil \\
\hline $\begin{array}{l}\text { Güemes- } \\
\text { Villahoz et al. } \\
\text { [21] }\end{array}$ & N/A & N/A & Conjunctivitis & $\begin{array}{l}\text { Conjunctival } \\
\text { swab }\end{array}$ & 25 & N/A & N/A & N/A \\
\hline
\end{tabular}

$N / A$ not available, $N P$ nasopharyngeal, $O P$ oropharyngeal, $P$ pharyngeal, $T C M$ traditional Chinese medicine

of each patient was RT-PCR-positive. These results highlighted the importance to collect multiple specimens serially to determine the true incidence of viral shedding in conjunctival secretions.

It has been postulated that after direct inoculation of infectious droplets, the conjunctiva may serve as a conduit system for viral entry through drainage along the nasolacrimal duct into the nasopharyngeal space, but is protected from direct viral invasion by the constant flushing of tear film and antimicrobial peptides and immunoglobulins in human tears [29]. Alternatively, the presence of low viral RNA load in the conjunctiva compared with that in the nasopharynx and in the absence of ocular symptoms might suggest retrograde migration of virus through the nasolacrimal duct from nasopharynx or hematogenous spread to the lacrimal gland. Obstruction of the nasolacrimal duct could prolong viral shedding in conjunctival secretions, as shown in a patient who had low SARS-CoV-2 RNA load in the eye swab detectable for 2 weeks after nasopharyngeal specimen turned negative while having no ocular symptoms all along [16]. In addition to direct infection of the conjunctival epithelium by SARS-CoV-2, ocular symptoms can also occur as a part of the systemic immunologic reaction to viral sepsis, since there seems to be an overall trend of higher prevalence 
of conjunctivitis in patients with more severe systemic manifestations [14]. Further studies are needed to elucidate the dynamic interaction of anatomic, physiologic, and immunologic factors on the conjunctival surface.

During the SARS epidemic in 2003, SARS-CoV RNA detection by RT-PCR from tear specimens of patients with probable SARS in the early phase of illness was reported in Singapore. In one of these patients, tear specimens were the only positive specimens used to confirm SARS [30]. Overall, conjunctivitis appeared to be a rare manifestation of other human-pathogenic coronavirus infections with the exception of HCoV-NL63, in which conjunctivitis was observed in as many as $17 \%$ of patients [31]. The report of conjunctivitis in human infections by SARS-CoV-2, SARS-CoV, and HCoV-NL-63 is consistent with the co-expression of the cell entry receptor angiotensin converting enzyme 2 (ACE2) and entry-associated protease transmembrane protease, serine 2 (TMPRSS2) on superficial conjunctival cells [32]. A recent study showed that SARS-CoV-2 is able to infect ex vivo cultures of human conjunctiva with greater competence than SARS-CoV [33]. In contrast to human-pathogenic coronaviruses, feline coronavirus (FCoV) is abundantly present in ocular tissues and secretions which represent an important infective source. Apart from conjunctivitis, FCoV is able to penetrate into deeper ocular compartments to cause pyogranulomatous anterior uveitis, choroiditis with retinal detachment and retinal vasculitis [34]. Non-human-pathogenic coronaviruses are frequent causes of ocular disease in other mammalian species, including mice, rats and pigs, following intraocular or oronasal inoculation [35]. High viral loads of Middle East respiratory syndrome coronavirus (MERS-CoV) have also been found in the conjunctival swabs of camels [36].

The finding of positive RT-PCR for SARS-CoV-2 from conjunctival swabs has significant implications for infection control. Although viral culture was negative for all the RT-PCR-positive specimens in our study, the possibility of infectivity cannot be totally eliminated due to the limit of detection by viral culture and small sample size. Notably, SARS-CoV-2 was isolated from the ocular swabs of a symptomatic patient with high viral load in Italy [15]. Since the start of the COVID-19 epidemic, ophthalmologists have been frequently reported to be infected by SARS-CoV-2, although it remains undetermined whether they acquired the infection through infectious conjunctival secretions as most of these cases occurred in confined space in which the exposed ophthalmologists and infected patients were in close proximity. Some of the routine examination procedures, e.g., noncontact tonometry, were potentially aerosol-generating. In addition, our findings demonstrated lower viral RNA loads in conjunctival swabs compared with nasopharyngeal or sputum specimens. Thus, with appropriate use of personal protective equipment, such as proactive face shields and compliance with hand hygiene, nosocomial transmission of SARS-CoV-2 during ophthalmology encounters should be minimized [37, 38].

Our study had limitations. The timing of collection of conjunctival swabs from recruited patients varied from 2 to 32 days after symptom onset, thus a definite timeline of conjunctival viral shedding could not be established. A total of 18 patients (36.7\%) had only one conjunctival swab collected and some of the patients had received antiviral treatment at the time or before conjunctival specimen collection, which might have led to an underestimated incidence rate of conjunctival viral shedding of SARS-CoV-2. In addition, the presence of SARS-CoV-2 in conjunctival secretions during the incubation phase/presymptomatic phase and after recovery cannot be determined here since all specimens were collected after laboratory diagnosis of COVID-19 during hospital stay, and no follow-up specimens were collected after discharge. We demonstrated in our study that patient with negative nasopharyngeal specimen can also have SARS-CoV-2 detected from conjunctival swabs (patient 1). However, further characterization of the relationship between nasopharyngeal and conjunctival detection of SARS-CoV-2 is not possible due to the small sample size of the current study. Larger studies with predefined time points and follow-up sampling are needed to further delineate the dynamics of SARS-CoV-2 shedding in conjunctival secretions. We reported the $\mathrm{Ct}$ values of the four positive conjunctival swabs, which likely represent relatively lower viral load in conjunctival secretions. For optimal statistical comparison, obtaining the viral load is more ideal in future studies.

In conclusion, in this prospective study, we demonstrated that SARS-CoV-2 shedding in conjunctival secretions occurred in $8.2 \%$ of ophthalmologically asymptomatic COVID-19 patients. These findings highlighted the importance of compliance with appropriate infection control measures, especially hand hygiene after contact with conjunctival secretions, during ophthalmological assessment of confirmed COVID-19 patients.

Author contributions XL: conceptualization, methodology, validation, formal analysis, data curation, writing — original draft. JFWC: conceptualization, methodology, validation, formal analysis, data curation, writing-review and editing, supervision. KKWL: validation, formal analysis, data curation, writing-review and editing. EYKT: investigation. CCYY: methodology, validation, formal analysis, data curation. SS: formal analysis, data curation, writing — review and editing. TWHC: investigation. KHYC: investigation. DLLH: investigation. AKLW: investigation. SKYC: investigation. RL: investigation. KCL: investigation. ART: investigation. VCCC: resources. KKWT: investigation. KHC: methodology, validation, formal analysis, data curation. KYY: conceptualization, resources, supervision. IFNH: investigation, resources, supervision.

Funding This study was partly supported by the donations of Richard Yu and Carol Yu, May Tam Mak Mei Yin, the Shaw Foundation Hong 
Kong, Michael Seak-Kan Tong, Respiratory Viral Research Foundation Limited, Hui Ming, Hui Hoy and Chow Sin Lan Charity Fund Limited, Chan Yin Chuen Memorial Charitable Foundation, Marina Man-Wai Lee, the Hong Kong Hainan Commercial Association South China Microbiology Research Fund, the Jessie \& George Ho Charitable Foundation, Perfect Shape Medical Limited, Kai Chong Tong, and Lo Ying Shek Chi Wai Foundation; and funding from the Consultancy Service for Enhancing Laboratory Surveillance of Emerging Infectious Diseases and Research Capability on Antimicrobial Resistance for Department of Health of the Hong Kong Special Administrative Region Government; and the Theme-Based Research Scheme (T11/707/15) of the Research Grants Council, Hong Kong Special Administrative Region. The funding sources had no role in the study design, data collection, analysis, interpretation, or writing of the report.

\section{Compliance with ethical standards}

Conflict of interest JF-WC has received travel Grants from Pfizer Corporation Hong Kong and Astellas Pharma Hong Kong Corporation Limited, and was an invited speaker for Gilead Sciences Hong Kong Limited and Luminex Corporation. SS has received speaker's honoraria from Abbott Laboratories Limited. The other authors declared no conflict of interests. The funding sources had no role in study design, data collection, analysis or interpretation or writing of the report. The corresponding authors had full access to all the data in the study and had final responsibility for the decision to submit for publication.

Ethics approval and consent to participate This study was approved by Institutional Review Board of the University of Hong Kong/Hospital Authority Hong Kong West Cluster.

Consent for publication Data records were de-identified and completely anonymous, so informed consent was waived.

Availability of data and materials The datasets used and/or analyzed during the current study are available from the corresponding author on reasonable request.

Code availability Not applicable.

\section{References}

1. Zhu N, Zhang D, Wang W, Li X, Yang B, Song J, et al. A novel coronavirus from patients with pneumonia in China, 2019. N Engl J Med. 2020;382(8):727-33. https://doi.org/10.1056/NEJMo a2001017.

2. Chan JF, Yuan S, Kok KH, To KK, Chu H, Yang J, et al. A familial cluster of pneumonia associated with the 2019 novel coronavirus indicating person-to-person transmission: a study of a family cluster. Lancet. 2020;395(10223):514-23. https://doi.org/10.1016/ s0140-6736(20)30154-9.

3. Chan JF, Kok KH, Zhu Z, Chu H, To KK, Yuan S, et al. Genomic characterization of the 2019 novel human-pathogenic coronavirus isolated from a patient with atypical pneumonia after visiting Wuhan. Emerg Microbes Infect. 2020;9(1):221-36. https://doi. org/10.1080/22221751.2020.1719902.

4. WHO. WHO Coronavirus Disease (COVID-19) Dashboard. World Health Organization. 2020. https://covid19.who.int. Accessed 23 Jun 2020

5. Guan W-J, Ni Z-Y, Hu Y, Liang W-H, Ou C-Q, He J-X, et al. Clinical characteristics of coronavirus disease 2019 in China.
N Engl J Med. 2020;382(18):1708-20. https://doi.org/10.1056/ NEJMoa2002032.

6. Huang C, Wang Y, Li X, Ren L, Zhao J, Hu Y, et al. Clinical features of patients infected with 2019 novel coronavirus in Wuhan, China. Lancet. 2020;395(10223):497-506. https://doi. org/10.1016/s0140-6736(20)30183-5.

7. Wang Y, Liu Y, Liu L, Wang X, Luo N, Li L. clinical outcomes in 55 patients with severe acute respiratory syndrome coronavirus 2 who were asymptomatic at hospital admission in Shenzhen, China. J Infect Dis. 2020;221(11):1770-4. https://doi.org/10.1093/ infdis/jiaa119.

8. Chan JF-W, Yip CC-Y, To KK-W, Tang TH-C, Wong SC-Y, Leung $\mathrm{K}-\mathrm{H}$, et al. Improved molecular diagnosis of COVID-19 by the novel, highly sensitive and specific COVID-19-RdRp/Hel realtime reverse transcription-PCR assay validated in vitro and with clinical specimens. J Clin Microbiol. 2020;58(5):e00310-e320. https://doi.org/10.1128/JCM.00310-20.

9. To KK-W, Tsang OT-Y, Leung W-S, Tam AR, Wu T-C, Lung $\mathrm{DC}$, et al. Temporal profiles of viral load in posterior oropharyngeal saliva samples and serum antibody responses during infection by SARS-CoV-2: an observational cohort study. The Lancet Infect Dis. 2020;20(5):565-74. https://doi.org/10.1016/S1473 -3099(20)30196-1.

10. Xia J, Tong J, Liu M, Shen Y, Guo D. Evaluation of coronavirus in tears and conjunctival secretions of patients with SARSCoV-2 infection. J Med Virol. 2020;92(6):589-94. https://doi. org/10.1002/jmv.25725.

11. Zhang X, Chen X, Chen L, Deng C, Zou X, Liu W, et al. The evidence of SARS-CoV-2 infection on ocular surface. Ocul Surf. 2020;18(3):360-2. https://doi.org/10.1016/j.jtos.2020.03.010.

12. Cheema M, Aghazadeh H, Nazarali S, Ting A, Hodges J, McFarlane A, et al. Keratoconjunctivitis as the initial medical presentation of the novel coronavirus disease 2019 (COVID-19). Can J Ophthalmol. 2020;S0008-4182(20):30305-7. https://doi. org/10.1016/j.jcjo.2020.03.003.

13. Chen L, Liu M, Zhang Z, Qiao K, Huang T, Chen M, et al. Ocular manifestations of a hospitalised patient with confirmed 2019 novel coronavirus disease. Br J Ophthalmol. 2020;104(6):748-51. https ://doi.org/10.1136/bjophthalmol-2020-316304.

14. Wu P, Duan F, Luo C, Liu Q, Qu X, Liang L, et al. Characteristics of ocular findings of patients with coronavirus disease 2019 (COVID-19) in Hubei Province, China. JAMA Ophthalmol. 2020;138(5):575-8. https://doi.org/10.1001/jamaophtha lmol.2020.1291.

15. Colavita F, Lapa D, Carletti F, Lalle E, Bordi L, Marsella P, et al. SARS-CoV-2 isolation from ocular secretions of a patient with COVID-19 in Italy with prolonged viral RNA detection. Ann Intern Med. 2020;173:242-3. https://doi.org/10.7326/M20-1176.

16. Hu Y, Chen T, Liu M, Zhang L, Wang F, Zhao S, et al. Positive detection of SARS-CoV-2 combined HSV1 and HHV6B virus nucleic acid in tear and conjunctival secretions of a non-conjunctivitis COVID-19 patient with obstruction of common lacrimal duct. Acta Ophthalmol. 2020. https://doi.org/10.1111/aos.14456.

17. Khavandi S, Tabibzadeh E, Naderan M, Shoar S. Corona virus disease-19 (COVID-19) presenting as conjunctivitis: atypically highrisk during a pandemic. Cont Lens Anter Eye. 2020;43(3):211-2. https://doi.org/10.1016/j.clae.2020.04.010.

18. Karimi S, Arabi A, Shahraki T, Safi S. Detection of severe acute respiratory syndrome Coronavirus- 2 in the tears of patients with Coronavirus disease 2019. Eye. 2020. https://doi.org/10.1038/ s41433-020-0965-2.

19. Valente P, Iarossi G, Federici M, Petroni S, Palma P, Cotugno $\mathrm{N}$, et al. Ocular manifestations and viral shedding in tears of pediatric patients with coronavirus disease 2019: a preliminary report. J AAPOS. 2020;S1091-8531(20):30115-24. https://doi. org/10.1016/j.jaapos.2020.05.002. 
20. Kumar K, Prakash AA, Gangasagara SB, Rathod SBL, Ravi $\mathrm{K}$, Rangaiah A, et al. Presence of viral RNA of SARS-CoV-2 in conjunctival swab specimens of COVID-19 patients. Indian J Ophthalmol. 2020;68(6):1015-7. https://doi.org/10.4103/ijo. IJO_1287_20.

21. Güemes-Villahoz N, Burgos-Blasco B, Arribi-Vilela A, Arriola-Villalobos P, Vidal-Villegas B, Mendez-Fernandez R, et al. SARS-CoV-2 RNA detection in tears and conjunctival secretions of COVID-19 patients with conjunctivitis. J Infect. 2020. https:// doi.org/10.1016/j.jinf.2020.05.070.

22. Hung IF-N, Lung K-C, Tso EY-K, Liu R, Chung TW-H, Chu M-Y, et al. Triple combination of interferon beta-1b, lopinavir-ritonavir, and ribavirin in the treatment of patients admitted to hospital with COVID-19: an open-label, randomised, phase 2 trial. The Lancet. 2020;395(10238):1695-704. https://doi.org/10.1016/S0140 $-6736(20) 31042-4$.

23. Hung IF-N, Cheng VC-C, Li X, Tam AR, Hung DL-L, Chiu $\mathrm{KH}-\mathrm{Y}$, et al. SARS-CoV-2 shedding and seroconversion among passengers quarantined after disembarking a cruise ship: a case series. The Lancet Infect Dis. 2020;20(9):1051-60. https://doi. org/10.1016/S1473-3099(20)30364-9.

24. Hung IF, Cheng VC, Wu AK, Tang BS, Chan KH, Chu CM, et al. Viral loads in clinical specimens and SARS manifestations. Emerg Infect Dis. 2004;10(9):1550-7. https://doi.org/10.3201/eid10 09.040058

25. To KK-W, Tsang OT-Y, Yip CC-Y, Chan K-H, Wu T-C, Chan JM-C, et al. Consistent detection of 2019 novel coronavirus in saliva. Clin Infect Dis. 2020;71:841-3. https://doi.org/10.1093/ $\mathrm{cid} / \mathrm{ciaa} 149$.

26. Yip CC-Y, Chan W-M, Ip JD, Seng CW-M, Leung K-H, Poon RW-S, et al. Nanopore sequencing reveals novel targets for detection and surveillance of human and avian influenza $\mathrm{A}$ viruses. J Clin Microbiol. 2020;58(5):e02127-e2219. https://doi. org/10.1128/JCM.02127-19.

27. Chu H, Chan JF-W, Yuen TT-T, Shuai H, Yuan S, Wang Y, et al. Comparative tropism, replication kinetics, and cell damage profiling of SARS-CoV-2 and SARS-CoV with implications for clinical manifestations, transmissibility, and laboratory studies of COVID19: an observational study. The Lancet Microbe. 2020;1(1):e14e23. https://doi.org/10.1016/S2666-5247(20)30004-5.

28. Lu C-W, Liu X-F, Jia Z-F. 2019-nCoV transmission through the ocular surface must not be ignored. Lancet (London, England). 2020;395(10224):e39. https://doi.org/10.1016/S0140 $-6736(20) 30313-5$.
29. Hong N, Yu W, Xia J, Shen Y, Yap M, Han W. Evaluation of ocular symptoms and tropism of SARS-CoV-2 in patients confirmed with COVID-19. Acta Ophthalmol. 98. https://doi.org/10.1111/ aos. 14445 .

30. Loon SC, Teoh SCB, Oon LLE, Se-Thoe SY, Ling AE, Leo YS, et al. The severe acute respiratory syndrome coronavirus in tears. Br J Ophthalmol. 2004;88(7):861-3. https://doi.org/10.1136/ bjo.2003.035931.

31. Vabret A, Mourez T, Dina J, van der Hoek L, Gouarin S, Petitjean $\mathrm{J}$, et al. Human coronavirus NL63, France. Emerg Infect Dis. 2005;11(8):1225-9. https://doi.org/10.3201/eid1108.050110.

32. Sungnak W, Huang N, Bécavin C, Berg M, Queen R, Litvinukova $\mathrm{M}$, et al. SARS-CoV-2 entry factors are highly expressed in nasal epithelial cells together with innate immune genes. Nat Med. 2020;26(5):681-7. https://doi.org/10.1038/s41591-020-0868-6.

33. Hui KPY, Cheung M-C, Perera RAPM, Ng K-C, Bui CHT, Ho $\mathrm{JCW}$, et al. Tropism, replication competence, and innate immune responses of the coronavirus SARS-CoV-2 in human respiratory tract and conjunctiva: an analysis in ex-vivo and in-vitro cultures. The Lancet Respir Med. 2020. https://doi.org/10.1016/S2213 -2600(20)30193-4.

34. Seah I, Agrawal R. Can the coronavirus disease 2019 (COVID-19) affect the eyes? A review of coronaviruses and ocular implications in humans and animals. Ocul Immunol Inflamm. 2020;28(3):3915. https://doi.org/10.1080/09273948.2020.1738501.

35. Belser JA, Rota PA, Tumpey TM. Ocular tropism of respiratory viruses. Microbiol Mol Biol Rev. 2013;77(1):144-56. https://doi. org/10.1128/MMBR.00058-12.

36. Chan JF, Lau SK, To KK, Cheng VC, Woo PC, Yuen KY. Middle East respiratory syndrome coronavirus: another zoonotic betacoronavirus causing SARS-like disease. Clin Microbiol Rev. 2015;28(2):465-522. https://doi.org/10.1128/cmr.00102-14.

37. Lai THT, Tang EWH, Chau SKY, Fung KSC, Li KKW. Stepping up infection control measures in ophthalmology during the novel coronavirus outbreak: an experience from Hong Kong. Graefes Arch Clin Exp Ophthalmol. 2020;258(5):1049-55. https://doi. org/10.1007/s00417-020-04641-8.

38. Tang SWT, et al. The Use of personal protective equipment in clinical ophthalmology during COVID-19: a review of international guidelines and literatures. Curr Opin Ophthalmol. 2020;31:435-46.

\section{Affiliations}

\section{Xin $\mathrm{Li}^{1}$ • Jasper Fuk-Woo Chan ${ }^{2,3,4,5}$ • Kenneth Kai-Wang $\mathrm{Li}^{6}$ • Eugene Yuk-Keung Tso ${ }^{7}$. Cyril Chik-Yan Yip ${ }^{1}$. Siddharth Sridhar ${ }^{2,3,4}$. Tom Wai-Hin Chung ${ }^{1} \cdot$ Kelvin Hei-Yeung Chiu ${ }^{1}$. Derek Ling-Lung Hung ${ }^{1}$. Alan Ka-Lun $\mathrm{Wu}^{8}$. Sandy Ka-Yee Chau ${ }^{9} \cdot \mathrm{Raymond} \mathrm{Liu}^{10} \cdot \mathrm{Kwok}$-Cheung Lung ${ }^{11}$. Anthony Raymond Tam ${ }^{13}$. Vincent Chi-Chung Cheng ${ }^{1} \cdot$ Kelvin Kai-Wang To ${ }^{2,3,4} \cdot$ Kwok-Hung Chan $^{2,3,4} \cdot$ Ivan Fan-Ngai Hung ${ }^{4,12,13}$. Kwok-Yung Yuen $2,3,4,5$}

1 Department of Microbiology, Queen Mary Hospital, Hong Kong Special Administrative Region, China

2 State Key Laboratory of Emerging Infectious Diseases, The University of Hong Kong, Pokfulam, Hong Kong Special Administrative Region, China

3 Department of Microbiology, Li Ka Shing Faculty of Medicine, The University of Hong Kong, Pokfulam, Hong Kong Special Administrative Region, China
4 Carol Yu Centre for Infection, The University of Hong Kong, Hong Kong Special Administrative Region, China

5 Hainan Medical University-The University of Hong Kong Joint Laboratory of Tropical Infectious Diseases, The University of Hong Kong, Pokfulam, Hong Kong Special Administrative Region, China

6 Department of Ophthalmology, United Christian Hospital, Hong Kong Special Administrative Region, China 
7 Department of Medicine, United Christian Hospital, Hong Kong Special Administrative Region, China

8 Department of Clinical Pathology, Pamela Youde Nethersole Eastern Hospital, Hong Kong Special Administrative Region, China

9 Department of Pathology, United Christian Hospital, Hong Kong Special Administrative Region, China

10 Department of Medicine, Ruttonjee and Tang Shiu Kin Hospital, Hong Kong Special Administrative Region, China
11 Department of Medicine, Pamela Youde Nethersole Eastern Hospital, Hong Kong Special Administrative Region, China

12 Department of Medicine, Li Ka Shing Faculty of Medicine, The University of Hong Kong, Pokfulam, Hong Kong Special Administrative Region, China

13 Department of Medicine, Queen Mary Hospital, Hong Kong Special Administrative Region, China 